
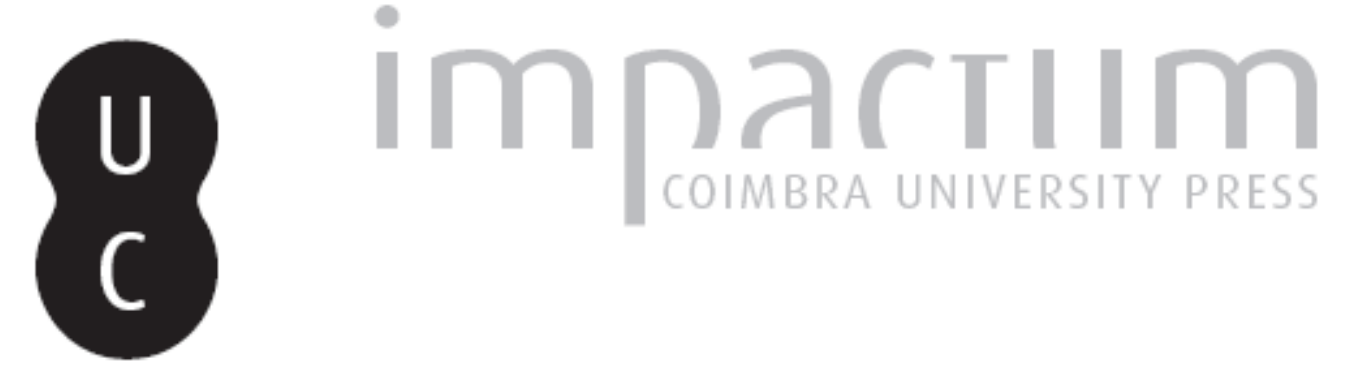

\title{
Os novos filhos da dor: Oriente e origem em Mllton Hatoum
}

\section{Autor(es): $\quad$ Ribeiro, Maria Aparecida}

Publicado por: Faculdade de Letras da Universidade de Coimbra

URL persistente:

URI:http://hdl.handle.net/10316.2/39983

DOI:

DOI:https://doi.org/10.14195/0870-4112_2_15

Accessed : $\quad$ 26-Apr-2023 05:17:41

A navegação consulta e descarregamento dos títulos inseridos nas Bibliotecas Digitais UC Digitalis, UC Pombalina e UC Impactum, pressupõem a aceitação plena e sem reservas dos Termos e Condições de Uso destas Bibliotecas Digitais, disponíveis em https://digitalis.uc.pt/pt-pt/termos.

Conforme exposto nos referidos Termos e Condições de Uso, o descarregamento de títulos de acesso restrito requer uma licença válida de autorização devendo o utilizador aceder ao(s) documento(s) a partir de um endereço de IP da instituição detentora da supramencionada licença.

Ao utilizador é apenas permitido o descarregamento para uso pessoal, pelo que o emprego do(s) título(s) descarregado(s) para outro fim, designadamente comercial, carece de autorização do respetivo autor ou editor da obra.

Na medida em que todas as obras da UC Digitalis se encontram protegidas pelo Código do Direito de Autor e Direitos Conexos e demais legislação aplicável, toda a cópia, parcial ou total, deste documento, nos casos em que é legalmente admitida, deverá conter ou fazer-se acompanhar por este aviso.

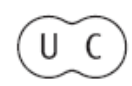


REVISTA DA FACULDADE DE LETRAS U N I VERS I A D E D E C O I M B RA 


\title{
Os Novos Fil hos da Dor ORIENTE E ORIGEM EM MILTON HATOUM
}

\begin{abstract}
:
Since the 18th century the construction of Brazil has been an ever-pre sent theme in Brazilian literature. In different but always celebratory ways, Santa Rita Durão, Alencar and Mário de Andrade have dealt with racial and cultural miscegenation. In the beginning of the $21^{\text {st }}$ century descendants of immigrants bring a new contribution to these earlier approaches. Among them. Milton Hatoum rethinks Brazilian history through his understanding of hybridism as a form of excessiveness counteracting a sense of the nation as a uniform totality.
\end{abstract}

\section{Fundações}

Ao comentar que "esta gente não lhes falece outra cousa, pera ser toda cristã, ca entenderem-nos" e que "o milhor fruito"l que os portu gueses poderão obter no Brasil será salvá-la, Pêro Vaz de Caminha aponta ao Rei D. Manuel dois veículos importantes para a dominação colonial: a língua e a religião. Envoltas em candura de fantasia (pois a ele "parece" que os índios desejam o Cristianismo), as palavras do escrivão encerram, porém, a promessa de atos de ruptura e violência de que darão conta a História e a Literatura, à medida em que forem sendo escritas e reescritas através dos tempos.

Visto ainda como qualificação e melhoria, o processo letal que atinge a cultura indígena, aparece, no século XVIII, por exemplo, no Caramuru, de Santa Rita Durão. Neste poema épico, a índia Paraguaçu, além de já conhecer a língua portuguesa, tem a mesma propensão dos nativos de Caminha para tornar-se cristã. E é pela religião que ela entrega sua terra e sua gente ao rei de Portugal. Durão não aborda propriamente a formação de um povo, de uma nação ou de uma raça: sobre os filhos do casamento da índia com o náufrago português - facto que tanto orgulho despertou nos baianos, a ponto de, no séc. XVII, Gregorio de Matos sati rizar a generalização de "paiaiás" com foros de "caramuru" — paira no

1 As citações da Carta de Pêro Vaz de Caminha obedecem à leitura de Pedro Serra, in Maria Aparecida Ribeiro, A Carta de Caminha e seus Ecos (Coimbra, Angelus Novus 2003) 232-233.

\section{Faculdade de Letras Universidade de Coimbra}


poema o mais absoluto silêncio; quem prospera é a colónia, o Brasil cris tão e obediente.

A ideia de povo surgirá tão somente no século XIX, depois da independência do Brasil. Um novo "poema épico", sob a forma de lenda, a lenda do Ceará, dará conta do chamado "encontro de culturas". Preo cupado em falar do surgimento de uma nova raça, José de Alencar, em Iracema (1865), abordará a mestiçagem étnica e cultural, acabando com o sentido único do projecto colonial. O narrador da lenda, cuja caracteriza ção fugiu certamente ao controle do escritor, será ele próprio um mestiço; sua língua, apesar de portuguesa, dá conta dos inúmeros empréstimos tupis e das várias derivas a que a sua transplantação deu origem ${ }^{2}$. E se o final do texto sintetiza, num conformismo evolucionista, com um "Tudo passa sobre a terra", a morte da cultura indígena, a lenda narrada é só apa rentemente uma história de amor. A violência colonial aparece denun ciada de forma alegórica, seja em comentários do narrador, seja em profecias das personagens, seja principalmente no nome dado ao mestiço que fica órfão: Moacir. Afinal, dizendo que a palavra significa "filho da minha dor", Iracema não fala apenas do sofrimento do parto e do aban dono a que Martim a devotou para cuidar das suas causas (a causa do seu rei e da sua religião), mas da dor ocasionada pelas sucessivas perdas: a de "virgem de Tupã"; a de membro da tribo tabajara, uma vez que foi morar entre os potiguaras, inimigos dos seus; e, finalmente, a da própria identi dade indígena, quando passou a residir sozinha com Martim, fora de qualquer aldeamento.

No início do século $\mathrm{XX}$, com os cem anos da Independência, a instalação da República e o advento das novas correntes estéticas, o Modernismo reviu a História nacional e, com ela, as ideias sobre mestiça gem. Obra paradigmática dessa revisão, Macunaíma (1927), de Mário de Andrade, dialoga com Iracema. "Sem nenhum carácter", porque adoles cente, o herói símbolo do Brasil não é mais apenas um filho de branco com índia. Produto híbrido e muíante, ele é também descendente do negro e partilha com o imigrante alguns de seus costumes. Nessa nova leitura, em que o brasileiro surge nascido de mãe índia, órfão e, ao mesmo tempo, filho de vários pais, a dor cede lugar ao riso, que corrói a História sob a forma de paródia, e a homogeneidade é substituída pelo multifário (pro cedimentos típicos do Modernismo), mas o ideal de nação (questionada

2 A respeito do assunto cf. Maria Aparecida Ribeiro, "O saí e a serpente: diálogos entre José de Alencar e Pinheiro Chagas", in Sentido que A Vida Faz-estudos para Óscar Lopes (Porto, Campo das Letras 1997) 377-389.

\section{Faculdade de Letras | Universidade de Coimbra}


ainda dentro dos tempos modernistas por Carlos Drummond de Andrade $^{3}$ ) permanece.

Com o aproximar-se do século XXI, começa a despontar na literatura brasileira uma outra saga, que aborda de uma outra perspectiva o problema da origem: não se trata mais de uma identidade brasileira una, idealizada, como o fruto do encontro mascaradamente pacífico entre um branco e uma índia, ou, deliciosamente carnavalizado, entre brancos, índios e negros. Tratam-se, agora, de várias fundações e de várias sagas, novas fantasias de origem. É o caso da literatura feita por filhos e netos de imigrantes, de que são exemplos as obras de Moacir Scliar, Samuel Rawet, Nélida Piñón, Salim Miguel e Milton Hatoum, do qual se ocupa o presente trabalho.

Descendente de libaneses e nascido em Manaus, em 1952, este último escritor traz para os seus textos a Amazónia, cenário das narrativas de vários viajantes, que lhe privilegiam o exotismo; de alguns romances realistas que procuram relacionar homem e meio; representante de um chão primordial, fracturado para dar origem ao Brasil, como a vêem alguns escritores modernistas, entre os quais Raul Bopp e Mário de Andrade.

Os três textos de Hatoum até hoje publicados - os romances Relato de Um Certo Oriente e Dois Irmãos (ambos detentores de um dos mais importantes prémios brasileiros, o Jabuti, da Câmara Brasileira do Livro, e ambos traduzidos para várias línguas e editados em Portugal, o que é um triunfo até maior que ser traduzido), e o conto "Dois Tempos" - mostram os contactos entre estrangeiros e nativos, a mestiçagem, as aproximações e diferenças culturais. Os dois primeiros mantendo com a anterior literatura brasileira fundacionista (mas não só com ela), um diá logo que convém analisar.

\section{O narrador e a memória}

"Aconselhado" pelos bustos pintados nas paredes de sua casa no Engenho Novo a reconstruir pela escrita os tempos idos, Bento San tiago, no romance D. Casmurro, lembra-se do poeta do Fausto e desta pergunta: "Aí Vindes Outra Vez, Inquietas Sombras?" A mesma indaga ção poderia ser feita por Milton Hatoum. Uma volta ao passado, uma

cł. o poema "Hino Nacional", incluído em Brejo das Almas. 
tentativa como a de Bento Santiago de "atar as duas ponías da vida"4, através da memória, é o que impulsiona tanto o Relato de um Certo Oriente, como Dois Irmãos e "Dois Tempos". Interessam-nos, para o caso presente, os dois romances.

Em Relato de um Certo Oriente, o mergulho no tempo é ten tado por uma mulher, que volta a Manaus, e, a instâncias do irmão, resi dente na Europa, munida de um caderno-diário, cartas, e até de um gravador, tenta reconstruir a infância perdida, a partir de testemunhos de pessoas vivas e de registos escritos por outras personagens já falecidas, num resgate que se aprofunda num tempo anterior ao de seu nascimento e que procura dar conta dos muitos enigmas que a cercam e à sua família de adopção.

Surgem, dessa forma, a sua própria voz e, por ela mediadas, a de Samara Délia, filha de Emilie; a de Hakim, "fonte de segredos" (Hatoum, 2001: 28), irmão de Samara, que retoma explicações dadas por Hindié Conceição, amiga de Emilie, e resgata o que lhe disse Dorner, antigo amigo da família, o qual, por sua vez, apontou o que lhe disse sobre o seu passado o marido de Emilie; a do próprio Dorner, e a de Hindié Conceição. O relato é, assim, simultaneamente, um texto alheio e um texto próprio, pois, se as lembranças não são da Narradora do Relato (daqui por diante chamada apenas Narradora), pertencem-lhe a ordenação das diferentes vozes e a selecção do material fragmentar:

Gravei várias fitas, enchi de anotações uma dezena de cadernos, mas fui incapaz de ordenar coisa com coisa. Confesso que as tentativas foram inúme ras e todas exaustivas, mas ao final de cada passagem, de cada depoimento, tudo se embaralhava em desconexas constelações de episódios, rumores de todos os cantos, fatos medíocres, datas e dados em abundância. Quando conseguia organi zar os episódios em desordem ou encadear vozes, então surgia uma lacuna onde habitavam o esquecimento e a hesitação: um espaço morto que minava a sequên cia das ideias. [...] Também me deparei com um outro problema: como transcre ver a fala engrolada de uns e o sotaque de outros? Tantas confidências em tâo poucos dias ressoavam como um coral de vozes dispersas. Restava então recorrer à minha própria voz, que planaria como um pássaro gigantesco e frágil sobre as outras vozes. (Hatoum, 2001: 165-166)

A Universidade vem, ao que parece, fugindo dessa orientação. Consulte-se na própria Internet os sites em que aparece o nome de Milton Hatoum, com particular atenção para o programa do Center for Latin Studies da University of California e para dissertação de Mestrado de Ana Claudia Silva Fidélis, defendida na Unicamp.

\section{Faculdade de Letras Universidade de Coimbra}


Esse questionamento da memoria, como realidade ou ficção, e da palavra, como forma de encobrimento, perspectiva que, na esteira de Machado de Assis ${ }^{5}$, relativiza o objetivismo realista, aparece também na voz de outras personagens. Dorner, por exemplo, diz a Hakim, referindo-se ao pai deste:

\section{[...] por muito tempo acreditei no que ele me contava, mas aos} poucos constatei que havia uma certa alusão àquele livro [As Mil e Uma Noites] e que os episódios de sua vida eram transcrições adulteradas de algumas noites, como se a voz da narradora ecoasse na fala do meu amigo. [...] Mas o curioso é que sempre deixava uma ponta de incerteza ou descrédito no que contava, sem nunca perder a entonação e o fervor dos que contam com convicção. Os fatos e incidentes ocorridos na família de Emilie e na vida da cidade também participavam das versões. Era como se inventasse uma verdade duvidosa que pertencia a ele e aos outros (Hatoum, 2001: 78-80).

Se gravações e notas não conseguem apreender a realidade de um tempo que se foi, também nas fotografias diluem-se os contornos da realidade: assim é com a fotografía de Emir, "protegida por uma lâmina de cristal", que podia evocar "um morto em Manaus e os do mundo inteiro" ou com as imagens registadas por Dorner para a "ilustração de aventuras" onde poderia haver os "erros clamorosos" de todo "viajante que procura o desconhecido" e "convive com a hipótese feliz de cometer enganos" (Hatoum, 2001: 80).

Uma imagem colocada no início do Relato, sob a forma de desenho infantil colado na parede - o remador que rema sem rumo, "porque nada no desenho dava sentido ao movimento da canoa" (Hatoum, 2001: 10) — é como que uma espécie de mise-en-abime da situação final de perplexidade da Narradora, diante de seus cadernos de anotações, fitas

\footnotetext{
5 Hatoum dialoga várias vezes com Machado e não só a respeito de realismo, verdade e verosimilhança, como acontece particularmente em D. Casmurro. Para não nos alongarmos valem estes exemplos: Dois Irmãos é uma outra forma de apresentar a passagem biblica de Esaú e Jaco, igualmente abordada pelo escritor carioca; ○ "gêmeo lacónico, carente de prosa", onde "crescia um matemático" que era Yaqub (Hatoum, 2000: 35) não deixa de ser uma versão das "ideias aritméticas" de Ezequel Escobar; tanto em Dois Irmãos, como no Relato de um Certo Oriente, o escritor faz questão de relacionar a história da família a diferentes momentos da história mundial, da brasileira e nomeadamente da história económica da Amazônia, à semelhança do que acontece com Machado (cf. John Gledson, Machado de Assis: fição e história (Rio de Janeiro, Paz e Terra 1986), (trad, de Sônia Coutinho), e Roberto Schwarz, Um Mestre na Periferia do Capitalismo: Machado de Assis (São Paulo, Duas Cidades 1990).
} 
gravadas e cartas do irmão: ela sente-se como "esse remador, sempre em movimento, mas perdido no movimento, aguilhoado pela tenacidade de querer escapar: movimento que conduz a outras águas, ainda mais confu sas, correndo por rumos incertos" (Hatoum, 2001: 10 e 165). O desenho do remador e a situação da Narradora encontram eco noutra falta de oriente - a foto de Emir, "um pouco antes de sua caminhada solitária que terminaria no cais do porto e no fundo do rio"; ela contava o que Dorner não foi capaz de dizer a Hakim: "o rosto tenso de um corpo que caminhava em círculo ou sem rumo" e cujo motivo era "um fato atroz", entrevisto nas cartas de Virginie Boulad (Hatoum, 2001: 60).

A falta de oriente (e lembremo-nos que oriente e origem têm a mesma raiz orior) é também a metáfora de uma outra ausência, já que a história da Narradora com a mãe é "a história de um desencontro" (Hatoum, 2001: 162). Ela e seu irmão, no espaço de dois anos que medeia os seus nascimentos, foram entregues a Emilie para que os criasse. Se, mais tarde, o filho teve a oportunidade de conviver um pouco com a mãe, para a filha, Narradora do Relato, ela é a voz "que nos abandonou há tanto tempo: uma voz dirigida à Emilie, sondando de um lugar distante, notícias da nossa vida" (Hatoum, 2001: 159), um rosto visto "uma única vez durante a infância" (Hatoum, 2001:162), "a voz de uma mulher que nunca pronunciou o meu nome" (Hatoum, 2001: 163), a possível respon sável pelo seu internamento numa clínica de repouso, onde a levou o desejo de se "enfronhar na realidade" (Hatoum, 2001: 135); o "contorno indefinido", a "forma envolta em sombras" que, certa noite, foi divisada na porta de seu quarto (Hatoum, 2001: 159); a visão da qual a interna se defende como se "estivesse de olhos vendados" ou assaltada por "uma cegueira súbita e precoce" (Hatoum, 2001: 159), a proprietária ausente da casa desconhecida, que ficava a 500 metros do sobrado de Emilie e para onde ela, Narradora, se dirige ao chegar a Manaus.

Essa ausência permanente ou "presença impossível”, "desco nhecido incrustado do outro lado do espelho", como Emilie dá a entender (Hatoum, 2001: 162), é a razão da demanda empreendida pela Narradora. Está sugerida na imagem encontrada ao rasgar um primeiro relato escrito na clínica, e fazer com o papel picado e alguns de seus bordados uma colagem: "O desenho acabado não representa nada, mas quem o observa com atenção pode associá-lo vagamente a um rosto informe. Sim, um rosto informe ou estilhaçado, talvez uma busca impossível neste desejo súbito de viajar para Manaus depois de uma longa ausência” (Hatoum, 2001: 163)

$\mathrm{O}$ rosto estilhaçado e a imagem do remador, desenho feito por uma criança - talvez ligada à dona da casa, possivelmente a Narradora

\section{Faculdade de Letras | Universidade de Coimbra}


ou seu irmão - unem-se, no final do Relato, como numa das sequências de Orfeu de Cocteau, quando o espelho em que se mira a princesa se que bra e ela o atravessa, caindo nas águas que brotam dos estilhaços e a levam para outra parte.

Esses fragmentos, porém, porque mediados pela voz da Narra dora, mostram as imagens que ela forma - embora nos avise que são falsas, lacunares, diluídas, frutos da imaginação - do (in)certo oriente em que foi criada.

Situação semelhante ocorre com o narrador de Dois Irmãos, também ele com um problema de identidade a resolver: filho de uma índia aculturada, Domingas, Nael busca saber, entre os fragmentos do passado - ora por ele lembrado, ora narrado pelos outros - qual dos gêmeos, se Yaqub, se Ornar, é o seu pai, numa demanda que resulta inútil. Mais uma vez, e pela boca do narrador, o texto de Milton Hatoum ques tiona a memória:

Talvez por esquecimento, ele me omitiu algumas cenas esquisi tas, mas a memória inventa, mesmo quando quer ser hei ao passado [...] Omissões, lacunas esquecimento. [...] Mas eu me lembro, sempre tive sede de lembranças, de um passado desconhecido, jogado sei lá em que praia do rio. (Hatoum, 2001: 98)

A imagem do rio, leitmotiv de Relato de Um Certo Oriente, volta mais uma vez. Agora não só para representar "as praias perdidas da memória", para usar um verso de Victor Matos e Sá, mas, novamente para mostrar a desorientação da personagem, embora dessa vez haja algum oriente:

Eu não sabia nada de mim, como vim ao mundo, de onde tinha vindo. A origem, as origens. Meu passado, de alguma forma palpitando na vida dos meus antepassados. Nada disso eu sabia. Minha infância, sem nenhum sinal de origem. E como esquecer uma criança num rio deserto, até que uma das margens a acolhe. Anos depois, desconfiei: um dos gémeos era meu pai. (Hatoum, 2000: 79).

\section{O (in)certo Oriente}

\section{1- O cenário}

Como diz Bachelard "no teatro do passado que é a nossa memória, o cenário mantém as personagens em seu papel dominante" (Bachelard, s.d: 24). Tanto no Relato de um Certo Oriente, quanto em 
Dois Irmãos, é para o espaço da infância que se procura dirigir o olhar de quem mergulha em tempos passados buscando compreender origens. Assim, se como já foi referido, a volta a Manaus serve de alavanca para a busca encetada pela Narradora, o primeiro cenário encontrado, seja o do exterior - a "espécie de gruta vegetal" e a humidade - seja o do interior da casa desconhecida - os tapetes de Kasher e íshafan, baús, ideogramas chineses, elefantes de porcelana, pagodes aquarelados e dragões, e o espelho que tudo reproduz como um caótico bazar - funciona como chave para um espaço de infância sempre assinalado, nas referências de quase todos os narradores secundários, pelo hibridismo entre Oriente e Ocidente. Por outro lado, o rosto da empregada, "filha de Anastácia e uma das afilhadas de Emilie", e o luxo dos aposentos do andar térreo da casa materna marcam desde logo duas regiões de fronteiras movediças, que no Brasil doutros tempos se chamaram casa-grande e senzala.

Outras referências espaciais também trazem esbatidas demar cações geográficas e sociais. E agora não só pelo fato de haver diferentes culturas em contacto: a profusão de narradores e a fragmentação tópica aliam-se à falta de um ponto de partida, um ponto de vista original da construtora do, funcionando como a falta de margens no desenho infantil pendurado na parede.

Algumas dessas cenas de contornos ambíguos são a vida por tuária, a profusão de feiras e mercados, o grito dos mascates e peixeiros, a tez morena das pessoas. O sentimento de indiferenciação é mais uma con sequência da construção do romance, motivada, por sua vez, pela impos sibilidade de alcance de um referencial identitário pela Narradora, que um dado inerente a cada personagem. Retomando uma observação de Hakim, personagem que possivelmente já conhecia o Líbano, o Relato diz que "as diferenças mais que as semelhanças, saltavam aos olhos" dos imigrantes (Hatoum, 2001: 28), mas

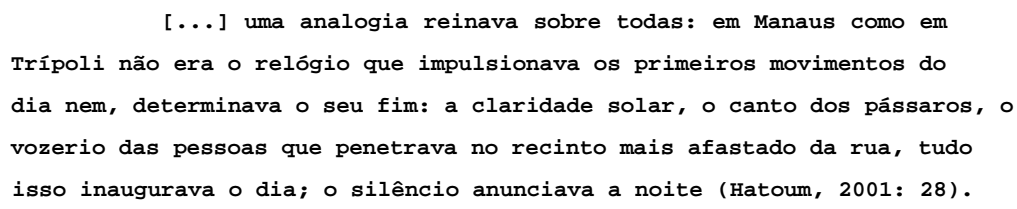

Em Dois Irmãos, também ocorre essa mistura, embora não exista propriamente um baralhamento de fronteiras. Talvez isto se deva ao fato de o narrador conhecer a identidade da mãe, uma cunhantã que ama sua terra e lhe transmite esse gosto, e também porque, como ele próprio afirma enxergou "de fora, aquele pequeno mundo"; "de fora e às vezes

\section{Faculdade de Letras | Universidade de Coimbra}


distante" (Hatoum, 2000: 33) — sua origem, sim, as uma origem que o coloca à margem. A seringueira, a mangueira, as palmeiras fazem-se pre sentes no exterior da casa de Zana, cujo interior não possui o mesmo acento oriental que a da Emilie, embora nas festas, as filhas de Talib dan cem ao som do alaúde e do darbuk.

Comum aos dois romances, a rede indígena marca a vida de todas as personagens, sejam elas mais, ou menos, ligadas ao Oriente. Na rede, Hakim recebe a notícia do acidente de Soraya Ángela; na rede explode o amor de Zana e Halim; a rede vermelha é o símbolo de Ornar; no fundo da rede a "neta" de Emilie, regressada a Manaus tem vontade de "aninhar-se" com ela.

\section{2- Perfumes e sabores}

Para a Narradora, o "aroma forte" que impregna a casa da mãe é identificado com "a cor, a forma e o sabor das frutas que arrancávamos das árvores que circundavam o pátio da outra casa”, a casa de Emilie (Hatoum, 2001: 10). Assim, a casa materna, desconhecida, conseguirá assemelhar-se à casa adoptiva conhecida, transformada em verdadeira matriz. Noutros momentos, ela falará da "polpa desse coração de veludo que é o jambo" (Hatoum, 2001: 15), de papoulas, orquídeas, begónias e tajás brancos (que convivem com parreiras), e de carneiros (criados com macacos e com a tartaruga Sálua), das imitações do bicho preguiça feitas por Soraya, mostrando até mesmo os cenários exteriores como híbridos. A Natureza privilegiada é, certamente, a amazónica, se bem que as suas cores e os seus perfumes possam evocar o Oriente.

As atividades reguladas apenas pela luz do sol - um tempo sem relógio - era talvez a única identificação de Emilie com o espaço para onde imigrara: ela rejeitava o saber dos médicos locais ("mal conse guem diagnosticar os vivos, como podem identificar uma pessoa exami nando a arcada dentária de um esqueleto?" (Hatoum, 2001: 67), as mulheres ("Tu achas que as caboclas olham para o céu e pensam em Deus? São umas espevitadas que se esfregam no mato com qualquer um e correm aqui para mendigar leite e uns trocados" (Hatoum, 2001: 87), a comida. Em sua casa, porém, atenuavam-se as fronteiras entre a sua terra natal e a terra de imigração. Decorada com uma série de objectos de ori gem europeia, trocados com o dono do restaurante Ville de Paris por Laure, a papagaia (outro elemento híbrido) que dizia frases em francês, também havia nela o narguilé (que exercia fascínio sobre Hakim), cum bucas de barro e redes, estas usadas por todos. Nas festas natalinas, o 
pinheiro substituía o cedro e, penduradas nele, havia bolas de sumaúma contendo caixinhas de chocolates recheados de castanha, numa associação de Brasil Sul, Líbano e Amazónia. À mesa, porém, na "miscelânea culiná ria" preparada por Hindié Conceição, Mentaha e Yasmine, as mulheres que "exalavam odores tão estranhos quanto seus nomes" (Hatoum, "2001: 23), o Oriente vencia. Comiam-se o carneiro assado com tâmaras, os doces de goma, de semolina com nozes e mel, as esfihas e folhados, as compotas de pétalas de rosa, "que todos aspiravam antes de provar" (Hatoum, 2001: 99 e 58). Com eles, e em fartura igual (a fartura parece ser um elemento comum à mesa amazónica e à oriental) conviviam a compota de goiaba, as tortas feitas com frutas da terra, os jenipapos, biribás, as pitombas e o maracujá do mato.

Nem sempre, porém, o Ocidente era representado apenas pela Amazónia, cuja flor do jambo Emilie elegia como adorno, quando se enfeitava nos aniversários de morte do irmão, ou cujos jasmins-do-mato eram espalhados no assoalho em reuniões que incluíam amigos, vizinhos e parentes. Havia os jarrões de porcelana que "se avultavam com as begó nias e tulipas" e os buquês de jasmins-porcelana e cansarinas róseas com prados aos franceses (Hatoum, 2001: 99).

É curioso observar, no Relato, como as diferentes gerações e as pessoas de diferentes origens se determinam com relação à comida. Em Hakim, o filho mais velho, criado entre esses dois mundos, as frutas da terra, "azedíssimas", causavam "calafrios no corpo e crispações no rosto"; já Anastácia Socorro, amazonense, "fazia careta quando degustava as frutinhas azedas, sem entender a origem dos cachos enormes das graúdas moscatéis" vindos do sul, ou fugia para não presenciar o "hábito gastro nómico milenar de comer com as mãos o fígado cru de carneiro" (Hatoum, 2001: 58 e 88). Emilie estabelecia fronteiras entre Brasil Norte e Brasil Sul, ao mesmo tempo que lançava pontes para o Líbano, quando falava do cupuaçu e da graviola: "São frutas para saciar o olfato, não a fome. [...] Só os figos da minha infância me deixavam estonteada desse jeito"” (Hatoum, 2001: 89). O odor, aliás, porque assunto de conversas, diluía as barreiras entre Anastácia e Emilie, funcionando como "ponta do novelo de histórias" sobre as cenas de infância que a levantina narrava à amazonense.

Em Dois Irmãos, Milton Hatoum não deixa de explorar cheiros e sabores, mas o hibridismo da casa de Zana, como já se disse, fica longe daquele que marca a casa de Emilie, apesar de Galib, realizar, no Líbano ou na Amazónia, transculturações culinárias e de Halim apreciar tanto o peixe frito com macaxeira enquanto como o arak. Até se poderia dizer

\section{Faculdade de Letras | Universidade de Coimbra}


que a Amazonia domina na ñora, na culinaria $\mathrm{e}$ nas mezinhas. A chegada de Yaqub - saudada pela mãe com um buquê de helicóneas — é feste jada por todos com guaraná e biscoitos de castanhas. Para assisti-lo, no desfile de 7 de Setembro, as mulheres da família levam "suco de abacaxi e uma sacola cheia de tucumãs" (Hatoum, 2000: 44). Omar, na volta de suas brigas e orgias, é tratado com banha de cacau, copaiba e folhas molhadas. Domingas associa-o, num devaneio imaginado por Nael, aos cheiros da fruta-pão e do cupuaçu sumarento, "fonte de raro perfume" (Hatoum, 200: 162)

Em Dois Irmãos, embora haja resistências à cultura do outro Domingas escondia-se para não ver a morte do "cordeirinho de Deus", executada por Halim e Nael, que "passava todo ano à espera do pernil" e ainda saboreava as fatias deixadas pela mãe (Hatoum, 2001: 93) —. há também troca de sinais: Yaqub, o gémeo que foi ao Líbano, leva farinha e pirarucu seco, para São Paulo, enquanto Ornar, já em pequeno fantasiado de "saguim de coleira", muito mais ligado à terra que o irmão, que pene tra e se deixa penetrar pela vida manauara, devora caixas de doces árabes quando está "exilado" na capital paulista.

\section{3 - Crenças e saberes}

A religião aparece nos dois romances como fator de aproxima ção entre empregada e patroa e de diferença entre marido e mulher. Anastácia Socorro e Emilie eram católicas; e Halim dizia que Domingas, ao vir para sua casa trazida pela freirá, era "uma menina mirrada, que chegou com a cabeça cheia de piolhos e rezas cristãs" e, com a mesma ponta de ironia do marido de Emilie, comentava em relação à cunhantã e Zana: "O que a religião é capaz de fazer. [...] Pode aproximar os opostos, o céu e a terra, a empregada e a patroa" (Hatoum, 2001: 69).

A mãe de Hakim e o marido, apesar de terem feito "pacto para respeitar a religião do outro, cabendo aos filhos optarem por uma das duas ou por nenhuma" (Hatoum, 2001: 69)", usavam-na como elemento de guerrilha. O muçulmano ironizava, dizendo a respeito de Laure, a papa gaia: "aqui no Amazonas os que repetem as palavras dos apóstolos são cobertos de penas coloridas e cagam na cabeça dos ímpios" (Hatoum, 2001: 26). Considerando um "martírio", "obra de cristão", o fato de Hindié embriagar as aves antes de matá-las, ele quebrou e escondeu ima gens de santos, o que originou também pequenas vinganças "religiosas" por parte de Emilie.

Católica, alfabetizada, e considerando-se superior aos da terra, a mãe de Samara deixava-se influenciar pelas crendices e saberes popula- 
res: maravilhada com as descrições que Anastácia Socorro fazia da flora regional, ela plantou, no fundo do quintal, "a trepadeira que espanta a inveja" e o tajá "que reproduz a fortuna de um homem" (Hatoum, 2001: 91) e cultivou a amizade de Lobato Naturidade, um índio que o pai de Hakim conhecera antes de casar-se, tio de Anastácia Socorro, "Príncipe da Magia Branca" no dizer de Dorner e conhecedor das propriedades das plantas. A Lobato, "representante de uma tradição ainda viva, que pulsava nos bairros da periferia" (Hatoum, 2001: 96), Emilie recorria nos casos de enfermidade. Mas o hibridismo, em matéria de crença e saberes não pára aí: ela também gostava de examinar o fundo das xícaras sujas do café com borra e decifrar, "no emaranhado de linhas negras do líquido ressequido" o destino de cada um (Hatoum, 2001: 31). E curiosamente, associava o marcar das horas, por sino e relógio, a um momento de êxtase e eterni dade $^{6}$. Já Domingas, conciliava, brasileiramente, cristianismo e supersti ção, como mostra o episódio da sugestão para que Zana, a fim de recuperar Ornar, dependure no pescoço um olho de boto.

O marido de Emilie, cujo nome jamais é citado (figura apagada pela personalidade forte da matriarca?), não é "esquivo aos da terra" e tem amigos entre eles. O comércio, o gosto pela conversa, o narguilé, são traços conservados da cultura oriental, com a qual ele mantém um diá logo, estabelecido através do rádio, sintonizando estações do Cairo e Beirute, trazendo-lhe notícias, música e "a voz possante de um muezim" que chegou a gravar, presenteando-a ao filho (Hatoum, 2001: 39). Mas é sobretudo a fidelidade ao Corão que o caracteriza.

O mesmo acontece a Halim, muito mais seguidor dos preceitos de sua religião que Zana, cujo cristianismo beira o comércio. Sua genero sidade, aliás, é questionada como a de Emilie $^{7}$. Se esta reclama que Anastácia Socorro "come como uma anta" e não lha dá o direito de provar das tâmaras que enchem a geladeira, aquela usa a comida que dá aos órfãos do internato $\mathrm{e}$ as roupas que envia para as índias das missões como forma de pressionar o diretor do colégio, quando este decide expulsar Ornar. A prática do norte parece ser comum às duas senhoras e dar conti-

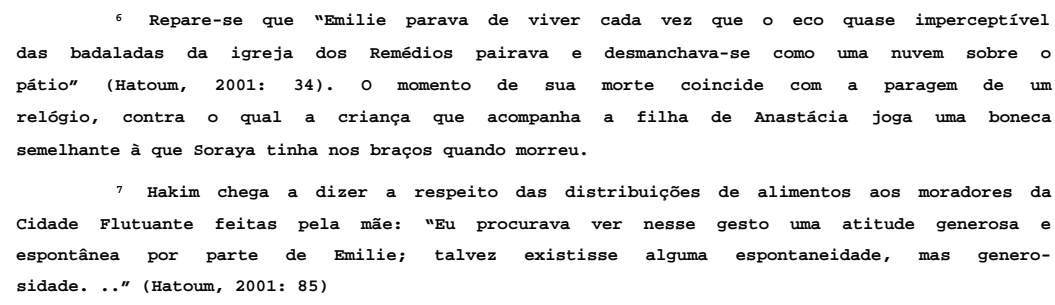

\section{Faculdade de Letras | Universidade de Coimbra}


nuidade à escravatura abolida na letra da lei, em 1888. No caso de Emilie, "as lavadeiras e empregadas da casa não recebiam um tostão para traba lhar" (Hatoum, 2001: 85); aos afilhados de Anastácia e aos seus sobrinhos ela arranjava várias tarefas, sem nada lhes pagar e sem lhes dar o direito de comer a mesma comida da família. Escondendo-se nas edículas ao lado do galinheiro na hora da refeição, a humilhação os transtornava até quando levavam à boca a colher de latão. Os "inomináveis" filhos de Emilie não admitiam a presença de Anastácia à mesa das refeições e "abusavam como podiam das empregadas, que às vezes entravam num dia e saíam no outro, marcadas pela violência física e moral" (Hatoum, 2001: 86), como Ornar fizera a Domingas, a "escrava fiel" (Hatoum, 2000: 39). $\mathrm{Na}$ casa de Zana, aliás, as relações entre casa-grande e senzala, podem ser observadas no tratamento dispensado a Nael: "Para Zana, eu só existia no rastro dos filhos dela" (Hatoum, 2000: 39). Mesmo sabido neto, ele era tratado como uma espécie de agregado, que "herdava" roupas e livros usados pelos gêmeos e executava, sem qualquer recompensa, tarefas para Rânia, para a avó-patroa e até mesmo para os vizinhos desta. Os fundos da casa foram e continuaram sendo, mesmo com a proteção de Yaqub, o seu lugar.

\section{4 - A língua}

Nos mundos confluentes da infância dos narradores, surge também a língua como um encontro das águas de "dois rios tempestuosos que se misturam para originar um terceiro" (Hatoum, 2001: 50), imagem que, aliás, Hatoum atribui a Hakim, lembrando a união das águas barren tas do Solimões com as escuras do Negro, para formar o Amazonas. São inúmeras as passagens do Relato a respeito do contacto linguístico.

Hakim, o filho eleito para aprender o árabe, aquele que desde pequeno conviveu com "um idioma na escola e nas ruas da cidade, e com um outro na Parisiense" (Hatoum, 2001: 52), recorda o contacto inicial como uma fala que ele pensara tratar-se de "uma linguagem só falada pelos mais idosos" (Hatoum, 2001: 29). A aprendizagem do idioma incluiu "a visita a espaços recônditos", uma "peregrinação", a que a variedade de objetos e a "caravana de odores" da Parisiense emprestava um clima oriental (Hatoum, 2001: 50). A penetração de Hakim na língua de seus pais foi assim uma iniciação no mundo deles e também uma mis tura de sonho e realidade, de conhecido e ignoto, enfim, um baralhamento de fronteiras: a história da transmissão de conhecimento de sua bisavó Salma para sua mãe, a morte daquela cercada de anjinhos, a voz do pai, 
"mais lúdica do que lúgubre", que tentou imitar logo que aprendeu o alfa beto e "antes mesmo de pronunciar uma única palavra na língua que, embora familiar, soava como a mais estrangeira das línguas estrangeiras" (Hatoum, 2001: 50)

A par do árabe, há outros idiomas no universo de memórias do Relato: o português, o nheengatu, o italiano, o francês, o alemão. Em vários momentos, a língua materna serve como um bilhete de identidade das personagens: é nela que eles se exprimem em sonhos ou em momen tos de dor, angústia e ódio, instaurando, por vezes, na comunicação com o outro, o muro de uma Babel. É assim quando Hindié Conceição tenta avi sar a Hector Dourado do acidente de Emilie, ou quando Dorner sabe do desparecimento de Emir:

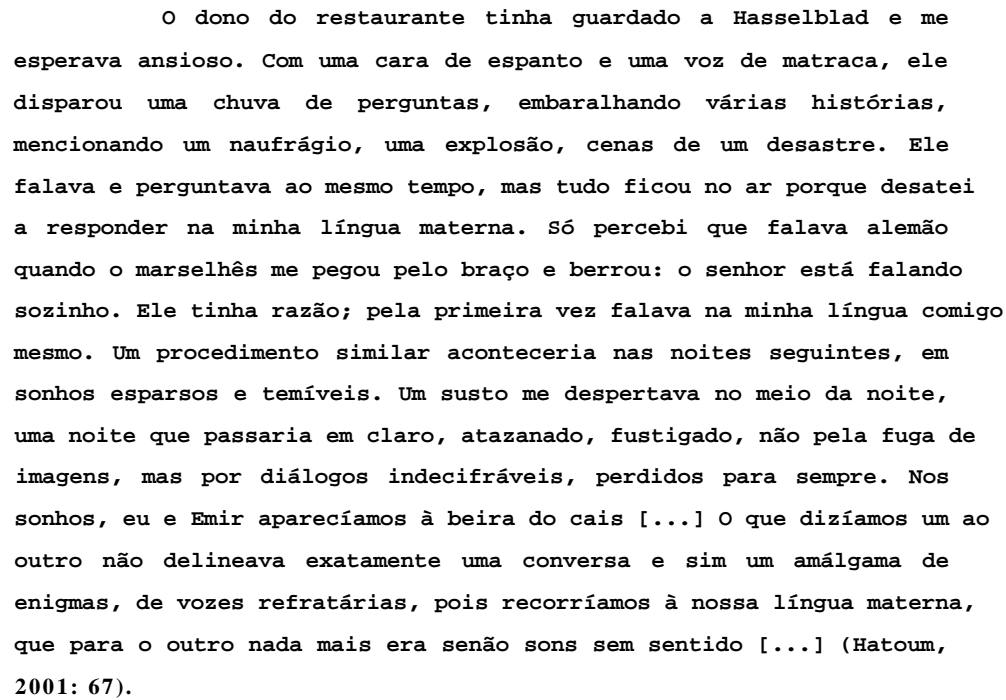

Emilie, que na memória da Narradora, inventava todos os dias um "idioma híbrido", muitas vezes ao recordar a infância, "sem se dar conta", nas conversas com Anastácia, "deixava escapar frases inteiras em árabe" (Hatoum, 2001: 166, 90). O francês era a sua língua de oração, que ela também lia em Português, como forma de aprendizado. No entanto, essa "travessia" de um idioma para outro podia soar "estranha ou infiel, como e alguns salmos e parábolas esbarrassem em pedras, tornando-se prolixos ou sem sentido" (Hatoum, 2001: 56).

Muitas vezes, Anastácia transportando a patroa e Hakim para "um mundo maravilhoso", o seu mundo, situado numa Amazônia mais

\section{Faculdade de Letras | Universidade de Coimbra}


profunda, fazia-os esbarrar nos "truques da língua brasileira", como lhes chamava Emilie que nunca transpusera os limites de Manaus, como, aliás, o filho mais velho. Era preciso, então, que a lavadeira funcionasse como um dicionário aberto, descrevendo, por exemplo, o pássaro de que falava e imitando o seu canto (Hatoum, 2001: 92).

Talvez pelo seu contacto com as populações ribeirinhas e pelo seu gosto pela conversa, as palavras de origem tupi ou as expressões utili zadas noutras localidades da Amazônia não constituíssem um impasse para o marido de Emilie, que chega mesmo a utilizar comparantes da terra, em suas observações (Hatoum, 2001: 37).

Em Dois Irmãos, o hibridismo linguístico é menos notório que no Relato. Mas, mesmo assim, é pela língua o mestiço Nael assume uma identidade amazonense, ao comentar o esforço feito por Yaqub para rea prender a língua da terra em que nascera, dizendo que ele foi "soletrando, cantando as palavras, até os sons dos nossos peixes, plantas e frutas, todo esse tupi não embolava mais na sua boca” (Hatoum, 2000: 35), e é ao árabe que Zana volta ao fim da vida, quando quer ser entendida apenas pela filha e por Emilie.

\section{A incerteza do Ocidente}

Quando o marido de Emilie, Hanna e Halim navegam para Ocidente, e aportam a Manaus buscam um mundo melhor e a prosperi dade. Não é isso, porém, o que encontram. Também não é isso que encontram, numa época posterior, Hakim, Samara Délia ou Yaqub, ou mesmo numa terceira geração, a Narradora do Relato e seu irmão. Os mais velhos observam que o comércio "exige malícia, destemor e o des caso (senão o desrespeito) a certos preceitos do Alcorão" (Hatoum, 2001: 75). Hanna, Halim e o marido de Emilie morrem pobres. Os mais jovens têm de sair. Manaus, mesmo a Manaus da mocidade de Emilie, que aí chega, em 1924, no final da Belle Époque (como que sugerem as datas citadas por Hindié), é uma cidade pequena, onde o morador "sem vínculo com a floresta e com o rio é um hóspede de uma prisão singular: aberta, mas unicamente para ela mesma” (Hatoum, 2001: 82). Assim testemu nham o relato de Dorner, a respeito da notícia da morte de Emir; a decepção do marido de Emilie, ao constatar que mais uma vez seu tio Hanna havia confundido imaginação e realidade; o louvor e os vitupérios dirigi dos contra Lobato Naturidade; a reprovação da amizade entre ele e Emilie e, simultaneamente, a consagração desta como "mãe de todos"; os livros comprados por Dorner e aqueles que Hakim lê e relê; o fato de Estelita 
Reinoso, viver do orgulho de sua família em ter hospedado o Rei Alberto; a inquirição movida contra os filhos inomináveis de Emilie sobre a vida de Samara Délia e a origem de Soraya Ángela; o diálogo de Dorner, "morador asceta da cidade ilhada", com o "Outro que é ele mesmo" (Hatoum, 200: 134 e 135); as palavras da Narradora do Relato a seu irmão:

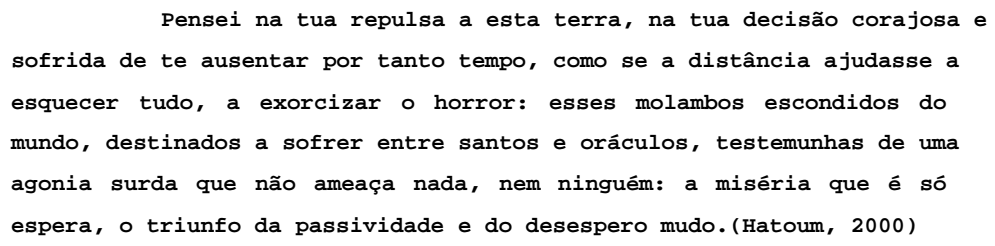

O Sul é o destino de Hakim, de Yaqub, da Narradora. São Paulo é a cidade que "crescia vertiginosamente, como Yaqub queria"; dela vai o dinheiro que reforma a casa de Zana e a loja da família; dela se comandam os destinos do Norte, acentuando as fronteiras dentro de um mesmo Brasil. Mas, para a Narradora, esse "emaranhado de torres cin zentas [...] onde a multidão se espreme em apartamentos ou em moradias construídas com tábuas e pedaços de cartão" era, além da clínica, o outro lugar da solidão e da loucura" (Hatoum, 2001: 160). Para Nael, o lugar de uma visita adiada por mais de vinte anos e que nunca se realiza; o lugar de onde Yaqub calculara a sua vingança contra a família que o rejeitara, onde habitava "a falácia do futuro que ainda persiste" (Hatoum, 2001: 289), o projecto que faz a cidade mutilar-se e "crescer ao mesmo tempo, afastada do porto e do rio, irreconciliável com o seu passado" (Hatoum, 2001: 291).

\section{A nova dor}

Quando Alencar escreveu $O$ Guarani e Iracema, esteve atento não só à mestiçagem étnica como também à cultural. Não foi à toa que ele apresentou um Peri desejoso de possuir uma pistola, ou com seu arco medievamente emplumado com as cores de Ceei. Martim transformado em Coatiabo, simbolizava a adopção de costumes indígenas pelo "estran geiro", embora, no final do romance, o narrador marque o triunfo da nova cultura, com o bronze substituindo o maracá e Poti mudando de nome, de língua e de religião. $\mathrm{O}$ seu romance foi redigido no Português do Brasil com as diferenças geográficas que lhe eram inerentes (ainda que o escritor

\section{Faculdade de Letras | Universidade de Coimbra}


disso só se desse conta depois da crítica de Pinheiro Chagas) e os empréstimos tupis, marca que ele conscientemente imprimiu e que estava no horizonte de expectativas de quem aguardava o exótico na literatura então emergente. Fato semelhante acontece com Mário de Andrade, quando alegoriza a mestiçagem na mudança de cor de pele de Macunaíma e nas "aquisições" culturais com que sobe ao céu (galinha, revólver e relógio), ou quando faz conviver a língua culta e a popular, os estrangei rismos e os tupinismos, a expressão dos cronistas e a de poetas posterio res, num verdadeiro memorial brasileiro. Ambos - "filho da dor" e "herói sem nenhum carácter" — são apresentados como símbolos da nação, respectivamente, recém-nascida e adolescente.

Em vários momentos de seus dois romances, Milton Hatoum chama a atenção para a pequenez manauara e para a gradativa degradação da cidade. As histórias pessoais neles narradas trazem à tona histórias de família, onde ninguém enriquece e todos partem, se quiserem buscar uma vida melhor, que acaba por não surgir. Em seus textos, a mestiçagem é assinalada como desmedida, como uma hybris que torna vulneráveis seus frutos; não como um pacto simbólico que consagra a nação. À cicatriz de Iracema, verbalizada no "Tudo passa sobre a terra", e à união entre flo resta e escola, esperança anunciada em Macunaíma, sucedem a incerteza e o desencanto. São Paulo, o Sul, deixa de ser o orgulho e a promessa da rapsódia de Mário de Andrade, para ser um espaço que contrasta com o Norte, que devora, revelando a ferida nacional.

A orfandade "original" da Narradora e de seu irmão, de Soraya Ángela, e de Nael, junta-se à de outras personagens como Anastácia Socorro e Domingas, e parece alegorizar o mesmo olhar perdido, o mesmo oriente incerto do remador que não vê as margens do rio, o mesmo "olhar à deriva" de Omar no final de Dois Irmãos. O Brasil idea lizado por Alencar, a partir da fractura de origem, ou por Mário de Andrade, que pode esperar a coerência de um Macunaíma adulto, vira estilhaço na obra de Milton: a inexistência de um ponto de vista único mistura as fronteiras entre eu e ele, Líbano e Amazónia, impossibilitando a narrativa que funda um povo ou uma nação. Como Drummond, Hatoum volta a afirmar "Nenhum Brasil existe". Mas vai além, e substitui o que é interrogação no poeta mineiro, pela constatação de uma nova dor: órfãos e sem oriente, tão pouco existem os brasileiros. 
Bibliografia

Bachelard, Gaston, A Poética do Espaço, (Rio de Janeiro, Livraria Eldorado Tijuca Lda., s.d.) (Trad, de António da Costa Leal e Lidia do Valle Santos Leal).

Hatoum, Milton, Dois Irmãos (Lisboa, Cotovia 2000).

Hatouin. Milton, "Dois Tempos", in Milton Hatoum et alii, Fotografia de Grupo (Lisboa, Cotovia 2003) 113-122.

Hatoum, Milton, Relato de Um Certo Oriente (São Paulo, Companhia das Letras 2001).

Ribeiro, Maria Aparecida, A Carta de Caminha e seus Ecos estudo e antologia (Coimbra, Angelus Novus 2003). 